\title{
Impacts of Foreign and Domestic Structural Shocks on Consumer Prices of the GCC Countries
}

\author{
Ashraf Nakibullah ${ }^{1}$ \\ ${ }^{1}$ Arab Open University - Bahrain Branch, Bahrain \\ Correspondence: Dr. Ashraf Nakibullah, Arab Open University - Bahrain Branch, P. O. Box: 18211, Bahrain. Tel: \\ 973-3985-7520.
}

Received: September 29, 2016

Accepted: October 13, 2016

Online Published: November 24, 2016

doi:10.5430/rwe.v7n2p34

URL: http://dx.doi.org/10.5430/rwe.v7n2p34

\begin{abstract}
This paper examines the relationship among exchange rates, oil price, foreign prices and the domestic consumer prices of the GCC countries. A SVAR model is used to identify variety of structural (both foreign and domestic) shocks and examine how the consumer prices of these countries react to these shocks. Results show that the consumer prices of these countries, except Bahrain and Kuwait, react positively to the exchange rate shocks. Consumer prices also react positively to oil price and foreign partners' price shocks. Impulse responses and variance decompositions generally support and complement the results found in other studies.
\end{abstract}

Keywords: exchange rates, pass-through, oil price, structural VAR

\section{Introduction}

Exchange rate pass-through has been a much discussed topic in recent years. It indicates the extent of the depreciation of the domestic currency passes through to the domestic price level and inflation. Empirical finding of low exchange rate pass-through to consumer prices has been termed as a "puzzle" and prompted Mishkin (2008) to comment that it is a kind of fiction created by the popular press. Empirical evidence from around the world find the presence of non-traded goods, transportation costs, tariff, stickiness of prices (and wages), importers unwillingness to pass to the consumer price index (CPI), size and structure of a country, monetary environment are among the many reasons for such a low level of pass-through to the CPI (Frankel et al., 2012). It is understandable that the impact seems to dissipate as it goes through stages from import prices (border or dockside prices) to retail (and local competitors') prices, and finally to the CPI. This dissipating effect has been found to be even more for the GCC countries (Bahrain, Kuwait, Oman, Qatar, Saudi Arabia and the UAE) because these countries provide generous subsidies to oil, gas, electricity, water and some food and essential items (Hasan and Nakibullah, 2015).

Besides the low pass-through effect in general, the studies of different countries over different time periods have also found wide variations in the pass-through coefficients. Shambaugh (2008) argues that the findings of the low pass-through and the wide variation are due to the fact that the macro-level studies (mentioned above among others) have not examined the root causes of the changes in exchange rates and prices. The wide variation is the effect of the different shocks hitting different countries at different times. The macro-level studies have focused on the correlation of exchange rates and prices. He constructs a simple example to show the drawbacks of the analysis based on the correlation of exchange rates and prices. For example, imported prices can be broken into foreign prices and exchange rates and if these last two components move in the opposite direction that may render no pass-through to the domestic prices. Instead of focusing on the correlation of exchange rates and prices, Shambaugh (2008) has identified the fundamental shocks to the economy and test their effects on exchange rates, consumer prices and other variables in the system. Following the structural vector autoregression (SVAR) approach of Blanchard and Quah (1989) and Clarida and Gali (1994), he uses an open-economy model to generate restrictions on long run behavior of the variables in the system. He uses panel data of 16 countries (mostly the European countries excluding GCC countries) over the period 1973:1 to 1994:4 and one of the general findings (among others) is that nominal shocks increase all nominal variables including exchange rates (both real and nominal), consumer prices and import prices.

Recently Kim and Hammoudeh (2013) have studied the impacts of domestic and foreign shocks on inflation of some of the GCC countries and Jordan. They have used a structural VAR model that includes nominal exchange rates, oil price, foreign prices (of individual countries), industrial production and consumer prices. In their study only half of 
the GCC countries (Kuwait, Oman, and Saudi Arabia) are included and their sample period covers monthly data from 1997 to 2011. The main emphasis of their study is to examine the viability of the proposed monetary union of the GCC countries and possibility of inclusion of Jordan in the union. That is, they examine whether shocks to industrial productions and inflation are synchronized.

This study covers all the GCC countries, uses the annual data that extended to the last four decades and uses more aggregated data. The emphasis of this study is also different. This study exclusively examines the foreign and exchange rates shocks on the consumer prices of the GCC countries. This way we can compare the results of the recent macro-level correlation studies (Hasan and Alogeel, 2008, Kandil and Morsy 2011 and Hasan and Nakibullah, 2015, and Nakibullah, 2016) relating exchange rates depreciation and inflation of the GCC countries.

\section{Some Common Features of the GCC Countries}

Besides their common language and tradition, production structure and consumption pattern are also similar. Here we discuss some common features that are relevant for understanding the variables that are including in the SVAR.

\subsection{Exchange Rates Arrangements}

The currency of Oman has been officially fixed to the US dollar since 1986. From 1980 to 2002, though the currencies of Bahrain, Qatar, Saudi Arabia and the UAE were de jure pegged to the Special Drawing Rights (SDR) basket of the IMF, they were de facto pegged to the US dollar. Their currencies have officially been pegged to the US dollar from 2003. Kuwait's currency had been pegged to an undisclosed basket of currencies till 2003. To comply with the proposed (but unmaterialized) GCC monetary union, Kuwait pegged its currency to the US dollar from 2003 to the middle of 2007 and then has returned to the basket peg. The US dollar has always been the dominating currency in the basket.

The exchange rate index used in this paper is the nominal effective exchange rate (NEER) of the US dollar. The NEER of the US dollar along the NEERs of each of the GCC countries are shown in Figure 1. They are trade-weighted indices. They are set in the standard way so that an increase in NEER indicates depreciation. Between 2002 to 2008 the US dollar depreciated against the major currencies more than $40 \%$ (Figure 1) and with it the GCC currencies also depreciated as we see the upward movement of these indices in Figure 1. However, the depreciations of the GCC currencies were lower and differ among the GCC countries. Since the GCC currencies are credibly pegged to the US dollar, they follow the monetary policy of the US as the nominal interest rates (money market rates) of the GCC countries shadow the federal funds rates of the US (Hassan et al., 2013). This means shocks to the consumer prices of the GCC countries (that we study in this paper) would come from the shocks in the US (base country). That is, the nominal shocks of the GCC countries would completely driven by the foreign shocks.

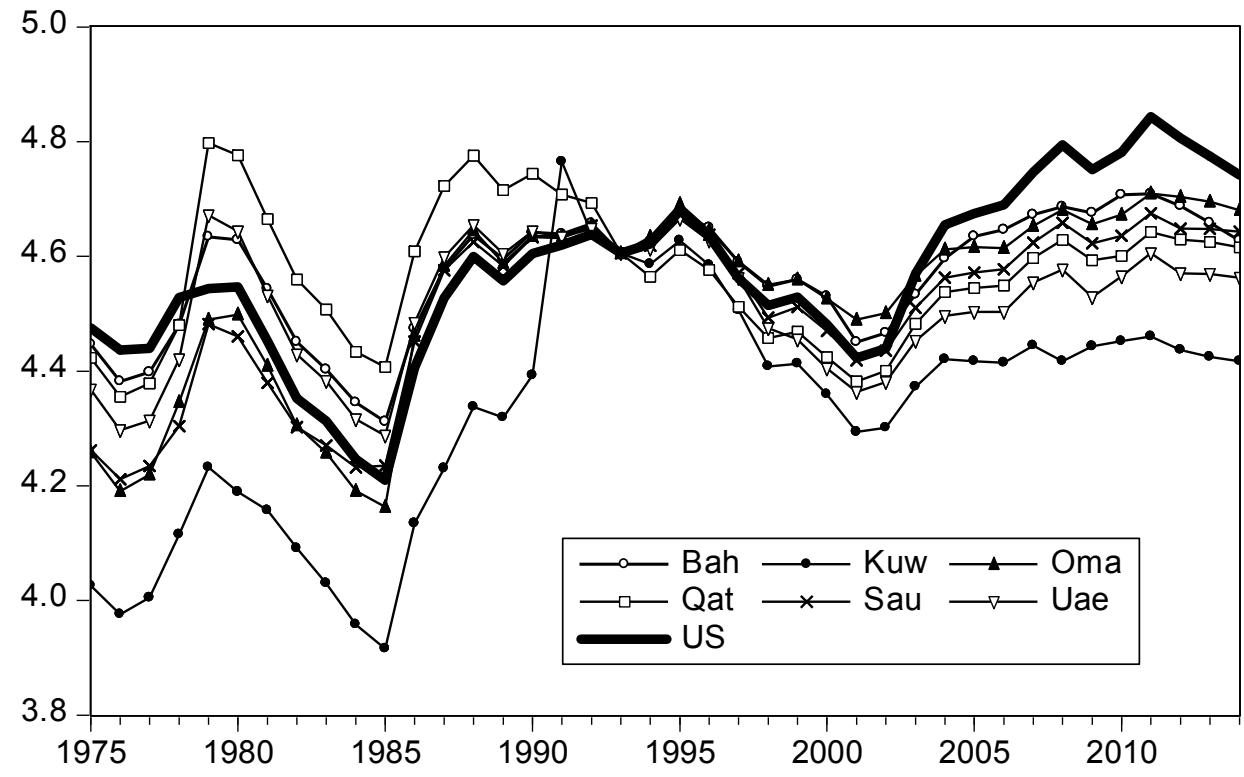

Figure 1. Nominal effective exchange rates indices of the US and GCC 


\subsection{Hydrocarbon Sector - Driver of the GCC Economies}

All GCC countries are oil-exporting countries. In terms of the size and the quantity of hydrocarbon exports, Saudi Arabia is the largest and Bahrain is the smallest. Naturally, either large or small, all their economic activities evolve around this hydrocarbon sector. Two-third or more of the government revenues comes from the oil related revenues as shown in Table 1. Non-oil revenues (taxes, investment income, fees and other charges) contribute the rest. Thus oil revenues play a major role in the government current expenditure. It is not surprising that the government spending is tied to the oil related revenues implying a positive correlation between government spending and oil prices (Espinoza and Senhadji, 2011). Oil-price induced government spending also stimulates non-oil GDP growth. For example, the recent cycle of construction and infrastructure boom in these countries coincided with the recent oil price hike. Transfer payments are also related to oil prices. The important point is that (global) shocks in oil prices influence the aggregate demand and supply of the GCC countries.

Table 1. Fiscal indicators of the GCC countries (Average 2000-09)

\begin{tabular}{lcccccc}
\hline \hline & Bahrain & Kuwait & Oman & Qatar & Saudi Arabia & UAE \\
\hline $\begin{array}{l}\text { Current government } \\
\text { expenditure/total } \\
\text { expenditure }\end{array}$ & 0.76 & 0.88 & 0.72 & 0.70 & 0.80 & 0.83 \\
$\begin{array}{l}\text { Government } \\
\text { expenditure/non-oil GDP }\end{array}$ & 0.36 & 0.79 & 0.66 & 0.64 & 0.66 & 0.36 \\
$\begin{array}{l}\text { Oil related revenues } \\
\text { Non-oil related revenues }\end{array}$ & 0.77 & 0.73 & 0.84 & 0.66 & 0.86 & 0.73 \\
& 0.23 & 0.27 & 0.16 & 0.34 & 0.14 & 0.27 \\
\hline \hline
\end{tabular}

Source: Espinoza and Senhadji (2011, table 1, p.4).

\section{Empirical Methodology}

The paper uses a SVAR to recover structural shocks to the GCC economies and tests the reactions of the consumer prices of the GCC countries. We follow the Blanchard-Quah (1989) methodology that utilizes the long-run identifying restrictions that certain shocks cannot affect the level of certain variables in the long-run. Given the oil-based economies of the GCC countries discussed above we assume the long-run restrictions as follows. The restrictions are that only exchange rate shocks can affect oil prices in the long-run, only exchange rate and oil price shocks can have a long-run impact on foreign prices, exchange rate, oil price, and foreign price shocks can have a long-run impact on domestic supply, and finally all these shocks and domestic supply shocks can affect domestic consumer prices.

Numerous studies have studied the relationship between oil prices and exchange rates. Some studies have found the causation runs from the exchange rates to the oil prices whereas some other studies have found the reverse causation. Kim and Hammoudeh (2013) and Zhang (2013) have reviewed some of this literature. One plausible explanation of the causation running from exchange rates to the oil price is found in Alhajji (2004). He argues that oil becomes cheaper in major currencies such as euro and yen when dollar depreciates against these currencies. This leads to higher world demand for oil and oil prices. From the suppliers (oil exporting countries) point of view, dollar depreciation reduces their purchasing power and to boost the oil price they curtail oil production. The World Bank (2014) has reported that the recent dollar appreciation was one of the causes of recent plunge in oil prices. It argues that a U.S. dollar depreciation tends to have a positive impact on the price of oil as demand can increase in countries that experience an increase in the purchasing power of their currencies against the dollar. It cites empirical estimates found in Zhang et al. (2008) and Akram (2009) where causation running from exchange rates to oil prices.

Reverse causation (causation running from oil prices to exchange rates) is also found in the literature. They argue that oil exporting countries have a preference for US-denominated assets. Thus, when oil price increases, the oil-exporting counties use the increased income to purchase US-denominated assets thus appreciating the dollar in the short-run. However, in the long-run, they use these increased income to purchase European and Japanese goods by exchanging dollar which eventually depreciates dollar (Zhang, 2013). As mentioned above, we impose the 
restriction that only exchange rate shocks can affect oil prices in the long-run. However, switching the ordering of exchange rates and oil prices do not change the regression coefficients and statistics because same variables are included.

Other long-run restrictions imposed follows from the standard macroeconomics and realities of the GCC countries. Foreign price level we use is a weighted average of the consumer price indices of the trading partners of the GCC countries which are mainly industrialized countries (Australia, the European countries, North America, Japan, and some emerging Asian countries). For these countries, oil is one of the raw materials of production and the cost of production and prices of these countries are directly to oil prices. We do not expect the supply of an individual GCC country can have any impact of foreign prices but foreign prices (trading partners' prices) can affect their aggregate demand and supply.

We express all variables in natural logarithm. Thus, variables are denoted as $e_{t}=\ln$ (NEER), $p o_{t}=\ln$ (oil price), $p_{t}^{*}=\ln$ (foreign trading partners' CPI), $y_{t}=\ln$ (real GDP) and $p_{t}=\ln (\mathrm{CPI})$. We have performed various unit root tests on levels of all variables in the system. Results show (not reported here) they are all characterized by nonstationary processes, however, they are all first difference stationary $I(1)$. We can represent the first differences of these variables as an infinite moving average representation (based on the ordering discussed above) as follows.

$$
\Delta x_{t}=A_{0} \varepsilon_{t}+A_{1} \varepsilon_{t-1}+A_{2} \varepsilon_{t-2}+\ldots \ldots \ldots=\sum_{i=0}^{\infty} L^{i} A_{i} \varepsilon_{t}
$$

where $\Delta$ is the first difference operator, $x$ is the vector of all five dependent variables [ordered $\left.e, p o, p^{*}, y, p\right], \varepsilon$ is the vector of five ( nominal exchange rate, oil price, foreign price, real output, and CPI) shocks [ordered $\varepsilon_{e}, \varepsilon_{p o}, \varepsilon_{p^{*}}, \varepsilon_{y}, \varepsilon_{p}$ ],$L$ is the lag operator, and $A_{i}$ are $5 \times 5$ matrices representing the impulse response functions of the shocks to the elements of $\Delta x$. We first estimate the following finite reduced-form VAR

$$
\Delta x_{t}=B_{1} \Delta x_{t-1}+B_{2} \Delta x_{t-2}+\ldots \ldots \ldots+B_{q} \Delta x_{t-q}+u_{t}
$$

where $u$ is the vector of residuals [ordered $u_{e}, u_{p o}, u_{p^{*}}, u_{y}, u_{p}$ ] obtained from estimating equation (2), $B^{\prime} s$ are

estimated coefficients and $q$ is the optimal lag length that ensures white noise residuals $u_{t}$. Note equation (2) can be represented as the following infinite moving average process

$$
\Delta x_{t}=(1-B(L))^{-1} u_{t}=u_{t}+R_{1} u_{t-1}+R_{t} u_{t-2}+\ldots \ldots \ldots \ldots=\sum_{i=0}^{\infty} L^{i} R_{i} u_{t}
$$

where $R_{0}$ is by definition is set to identity matrix. We assume that there exists a non-singular matrix $C$ such that

$$
u_{t}=C \varepsilon_{t} \text {. }
$$

Restrictions are needed to identify the elements of $C$ so that we can recover shocks $\varepsilon_{t}$ from the regression residuals $u_{t}$. One of the restrictions is that the structural shocks $\varepsilon_{t}$ are orthonormal, that is, its covariance matrix is an identity matrix $E\left(\varepsilon_{t} \varepsilon_{t}^{\prime}\right)=I$. Matrix $C$ is still not identified and we need to add more restrictions. These added restrictions are coming from the long-run restrictions on shocks that we have assumed and discussed above. The recovered (identified) shocks are then used to obtain impulse responses and variance decompositions. 


\section{Data and Empirical Results}

\subsection{Data}

Annul data are used covering the period from 1975 to 2014 (the latest data available). We use annual data because quarterly (monthly) data for real GDP (measure of our output $y$ of GCC countries) are not available at all and for some variables quarterly data are available only for recent times mostly after 1990s or even after 2000s. The consumer price indices (CPIs) of the trading partners (US, Japan, Germany, UK, China, Italy, Korea, France, Australia and India) of the GCC countries are used to calculate a trade-weighted or GDP-weighted index of foreign price level $\left(p^{*}\right)$ as discussed in Hasan and Nakibullah (2015). These trading partners' GDPs and CPIs are taken from the World Economic Outlook (WEO) database from various years. The nominal effective exchange rate of the US dollar is taken as the measure of exchange rate. It is a trade weighted value of the US dollar against major currencies of Euro Area, Canada, Japan, U.K. and Switzerland. It is taken from Federal Reserve of St. Louis. Thus, exchange rate, oil price and foreign price index are the same for all GCC countries. Real GDP and CPIs are country specific for each of the GCC country. They are taken from the WEO database.

\subsection{Empirical Results}

As mentioned above, unit root tests show (not reported here) that all five dependent variables in the system are integrated of first order, $I(1)$. We first estimate five variables VAR model for several lag lengths for each of the GCC countries. A dummy for Kuwait is added for the years 1990 and 1991; this is to capture the Iraqi invasion of Kuwait in 1990 and a subsequent Gulf war in 1991. To ensure white noise residuals $u_{t}$, optimal lag lengths are chosen based on standard criteria such as Akaike, Hannan-Quinn and Schwarz information criteria. Then recovered structural shocks $\varepsilon_{t}$ (as discussed above) are used to obtain impulse responses shown in following figures and variance decompositions shown in following table.

The responses shown here are the accumulated responses which are the log level of CPIs. Thus, when a CPI has changed by 0.01 , it will be interpreted as a $1 \%$ change in the level of the variable in response to a one standard deviation in the shock. The response at time $t=1$ is the contemporaneous (instantaneous or temporary) response following any shock. Our main interest is to find out the responses of the CPIs following domestic and foreign shocks (exchange rates, oil price and foreign trading partners' prices). We just note (without reporting here) that in response to exchange rate (depreciation) shock, the trade-weighted value of the US dollar rises by $5 \%$ instantaneously and then permanently rises to $8 \%$. The exchange rate depreciation shock raises the oil price and the oil price shock raises the foreign trading partners' prices permanently.

\subsubsection{Exchange Rate Depreciation Shocks}

The relationship between exchange rates and prices is a much discussed topic of the recent exchange rate pass-through literature. Thus, we first look at the responses of the consumer prices (CPIs) of the GCC countries following the trade weighted US dollar depreciation shocks and this is reported in figure 2. As we see in figure 2, the US dollar depreciation shocks lower the CPIs of Bahrain and Kuwait instantaneously; a surprising result also obtained in recent macro-level correlation studies (see, for examples, Kandil and Morsy, 2011 and Hasan and Nakibullah, 2015). Moreover, such shocks create permanent deflation (negative changes in price level) for these countries. One may explain this surprising result in terms of wealth effect. When the exchange rate depreciates, it decreases real wealth thereby depresses demand and deflation in the long-run. However, if this is true then why it is not happening to other GCC countries after all they have similar production structure and consumption pattern; they have also similar portfolio selection. The result of Kuwait is particularly interesting. Studies from both the macro-level correlation studies and this structural shock generating studies show that the exchange rate depreciation induces long-run deflation in Kuwait. Kuwait government (the Central Bank of Kuwait) thought the opposite. Kuwait blamed the recent prolonged dollar depreciation $(2002-2007)$ as the main cause of their recent $(2002-2007)$ accelerated inflation and as a result it switched from dollar peg to basket of currencies (Strum et al., 2008). Such blame seems unwarranted. 


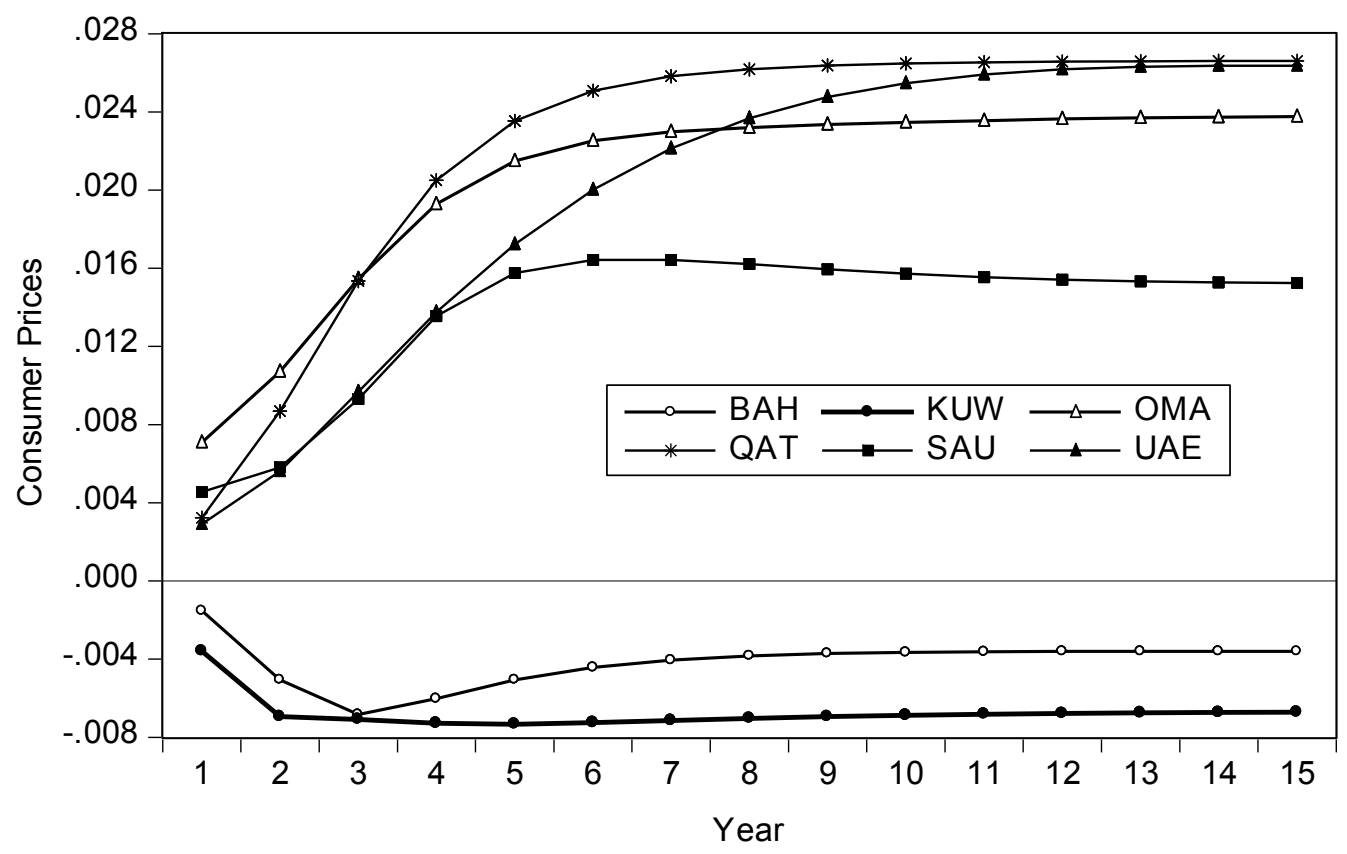

Figure 2. Cumulative response of CPIs to exchange rate shock

The dollar depreciation shock raises the prices of Oman, Qatar, Saudi Arabia, and the UAE instantaneously and permanently (Figure 2). The degree of long-run pass-through seems to be highest for Qatar followed by the UAE. The prices of Qatar and the UAE rise by about $2.5 \%$ in the long-run. The prices of Oman and Saudi Arabia rise by $2.2 \%$ and $1.6 \%$, respectively, in the long-run. These results differ from the results obtained from correlation studies mentioned above and shows the merit of long-run restrictions VAR to identify shocks.

\subsubsection{Oil price Shocks}

The responses of the domestic GCC consumer prices to oil price shocks are presented in Figure 3. In response to the shock, the consumer prices rise instantly and permanently for all GCC countries, though the increase is much smaller for Bahrain and Saudi Arabia compared to other countries especially to Qatar. These results differ from the results found in Hasan and Nakibullah (2015); however, these results are expected given that they are all oil-exporting countries and depend heavily on imported consumer goods. When dollar depreciates against the major currencies, world oil price increases (World Bank, 2014). Government revenues (and transfer payments) of the GCC countries increase with the increase in oil price which is turn increases spending (both government and private). This raises aggregate demand and consumer prices. The case in point is the recent (2002-2007) accelerated inflation in these countries when dollar depreciation and the hike in oil price coincided. During this time Qatar experienced the highest accelerated inflation compared to other GCC countries (Sturm et al., 2008). Figure 3 shows that Qatar's CPI instantly rises by $1.4 \%$ and $3.8 \%$ in the long run following the oil price shock. This makes sense because Qatar's economic position has improved dramatically since 1999 with the rise in the production of liquefied natural gas (LNG) and crude oil output. In response of oil price shock, the CPIs of Kuwait, Oman, and the UAE rise by $3.9 \%$, 3.5\%, and $2.9 \%$, respectively, in the long-run. Recently, Kuwait also experienced an accelerated inflation as close to Qatar. The lowest long-run responses are obtained for Bahrain (1.5\%) and Saudi Arabia (1.4\%). These two countries experienced the lowest recent inflation. 


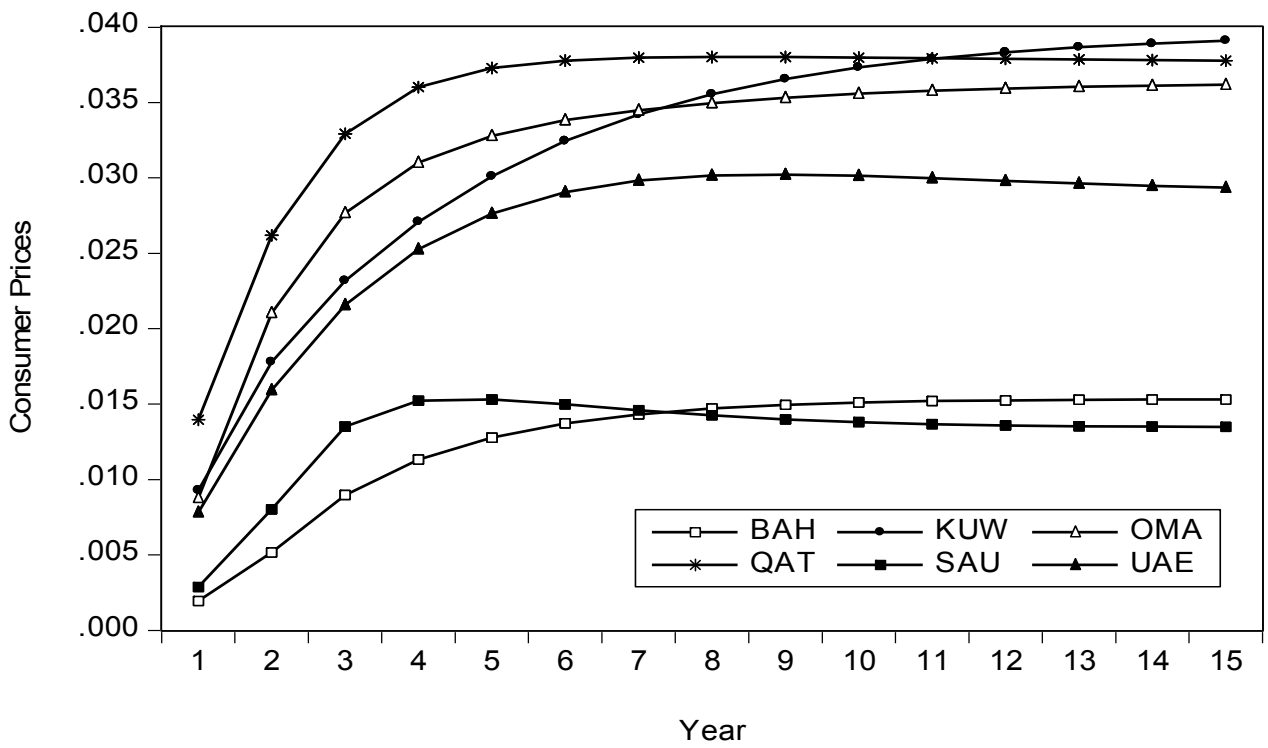

Figure 3. Cumulative response of CPIs of the GCC countries to oil price shock

\subsubsection{Foreign Trading Partners' Price Shocks}

The responses of the consumer prices to foreign trading partners' price shock are presented in Figure 4. Recent correlation studies show that the foreign trading partners' price level is main short-run and long-run determinant of these countries' CPIs (see, for examples, Hasan and Nakibullah, 2015 and Nakibullah, 2016). Thus, it is not surprising that foreign price shocks affect consumer prices of these countries instantaneously and permanently as we see in figure 4. It is clear from figure 4 that the trading partners' price shock is the source of the imported inflation in the GCC countries. Foreign price shock instantly raises the CPI of the UAE by $1.6 \%$ and continues to rise till 6 years then starts to fade till it stabilizes at $4.5 \%$ in the long-run. Figure 4 shows Bahrain and Saudi Arabia experience the highest and the lowest imported inflation, respectively. This is in line with the reality that Bahrain has the highest and Saudi Arabia has the lowest import penetration ratios among all GCC countries (Hasan and Nakibullah, 2015). The CPI of Bahrain rises by $1.2 \%$ instantly and moves up to $4.9 \%$ in the long-run. In response to foreign price shock, the CPI of Saudi Arabia fades away after an initial increase. It stabilizes to $1.1 \%$ in the long-run. The CPIs of Kuwait and Oman stabilize around $4.3 \%$ in the long-run after an initial fairly large reaction. After an initial increase, the CPI of Qatar settles quickly to $2.7 \%$ in the long-run. This lower impact is probably due to the higher impact of oil price shock (Figure 3) due to its flourish in recent years.

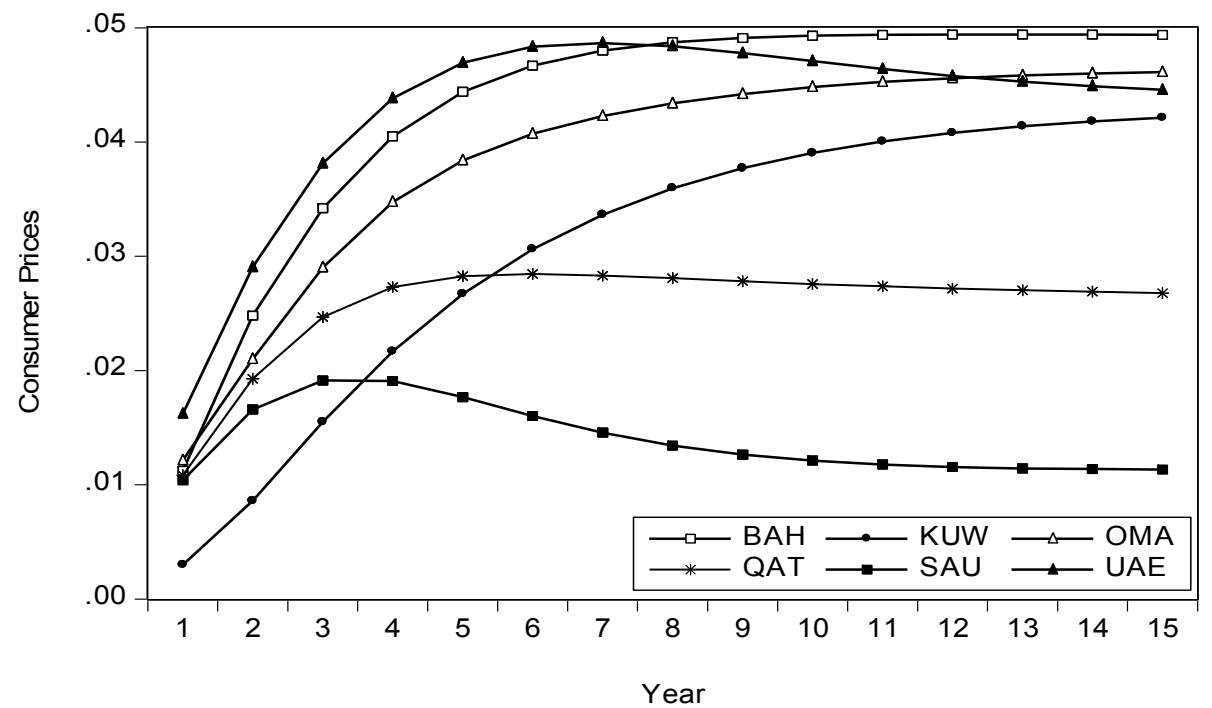

Figure 4. Cumulative response of CPIs of the GCC countries to foreign price shock 


\subsubsection{Domestic Supply Shocks}

Responses of the consumer prices to domestic supply shocks are presented in figure 5. We expect supply (productivity) shocks would lower prices (both GDP deflator and consumer prices). However, as we see from Figure 5 that such expectation is not met except for Oman and somewhat for Kuwait. Following the supply shocks, the consumer prices of Oman decreases by $1.5 \%$ instantly and settles at $-2.5 \%$ in the long-run. The consumer prices of Kuwait decreases instantly by $1 \%$ and quickly settles at that level in the long-run. For other GCC countries supply shocks lift consumer prices permanently where Qatar leads the way. These results are not at all without precedent. For example, Bayoumi and Eichengreen (1994) have found positive reaction to prices following supply shocks for Western Canada, North-West and South-West of the United States whose economies like the GCC economies also heavily rely on oil and natural gas production. Argument here is that for such oil based economies a positive supply shock could be offset by the accompanied demand shock which ultimately raises prices.

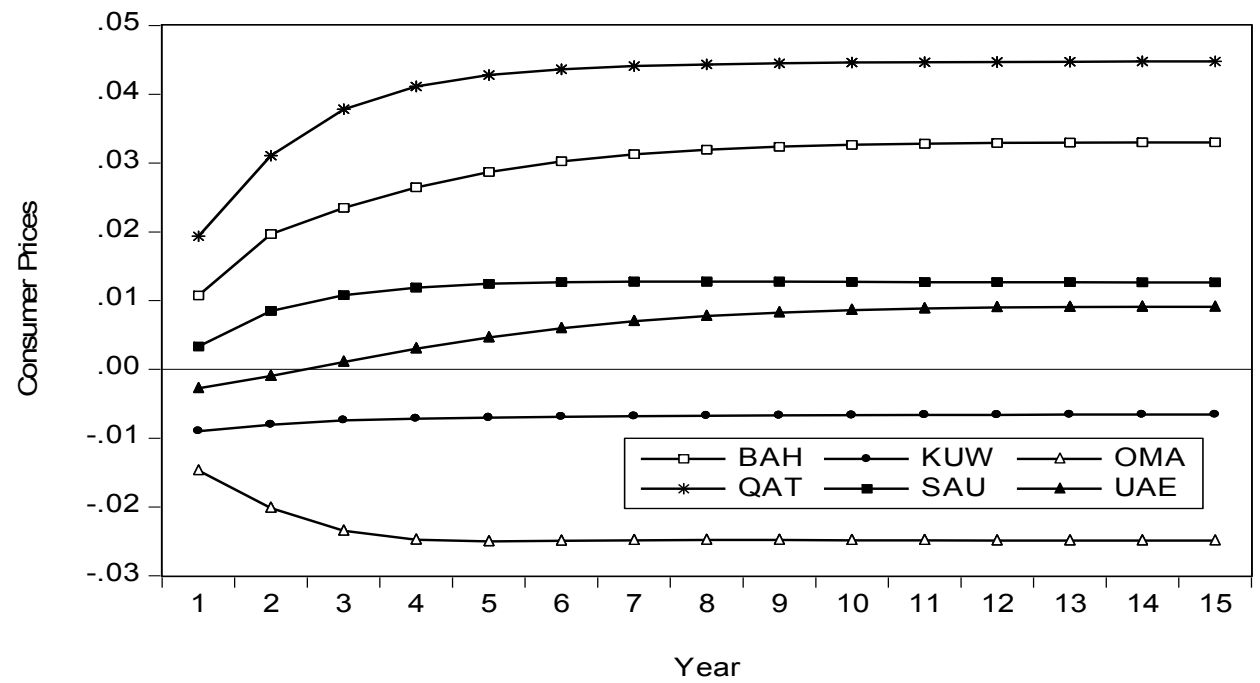

Figure 5. Cumulative response of CPIs of the GCC countries to supply shocks

\subsubsection{CPI (Nominal) Shocks}

As expected nominal shocks have a positive impact on consumer prices of the GCC countries as we see in figure 6. The consumer prices reaction is much smaller or slower for Bahrain, Kuwait and Saudi Arabia probably due to their generous subsidies.

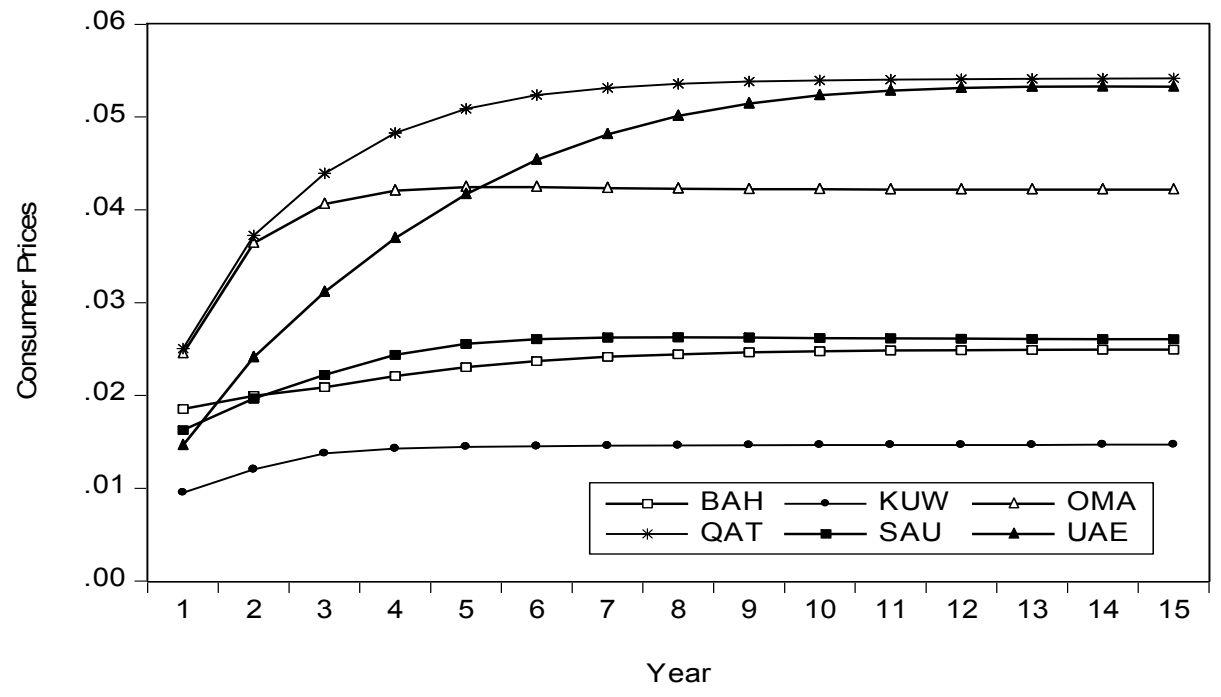

Figure 6. Cumulative response of CPIs of the GCC countries to CPI shocks 
Though Oman and Qatar's prices have same temporary increase, consumer prices of Oman fade quickly to $4.2 \%$ in the long-run. Prices rise almost instantly to their long-run levels for Bahrain, Kuwait and Saudi Arabia though the temporary reaction is smaller for Kuwait (1\%). Price reaction is highest for Qatar and the UAE though their trajectories are different; prices of the UAE rise more slowly. Both of them rise to about $5 \%$ in the long-run. Price reactions of Qatar and the UAE reflect their accelerated development compared to other GCC countries.

\section{Variance Decompositions}

As in impulse responses, we only report variance decompositions of the percentage change in consumer prices. Variance decompositions show how each of the five shocks determines the log change in consumer prices (inflation) of each of the GCC countries. Table 2 shows the (structural) variance decompositions at time intervals (forecasting horizons) $1-4$ and at time 6 . As we have seen above that consumer prices are not driven by one type of shock and also reactions of different shocks are different for different GCC countries. This means different countries would have different variance decompositions. We see in table 2 that consumer prices are driven by many different shocks. Own CPI shocks are the most significant shocks for Oman (43\%), Qatar (39\%) and Saudi Arabia (47\%). In addition to own CPI shows, foreign price shocks are also important for Oman and Saudi Arabia whereas supply shocks are important for Qatar. The foreign price shocks are the major sources of fluctuations in the consumer prices of Bahrain $(42 \%)$ and the UAE (44\%). Their own CPI shocks are also very important. Kuwait is the only country for which oil price shocks play the major role in the fluctuations of its CPI. Foreign price shocks also play an important role.

Table 2. Variance decompositions of percentage (\%) change in CPI

\begin{tabular}{lcccccc}
\hline \hline \multirow{2}{*}{ Country } & $\begin{array}{c}\text { Shocks } \rightarrow \\
\text { Time } \downarrow\end{array}$ & $\begin{array}{c}\text { Exchange } \\
\text { rate }\end{array}$ & Oil price & $\begin{array}{c}\text { Foreign } \\
\text { price }\end{array}$ & Supply & CPI \\
\hline Bahrain & 1 & 0.39 & 0.64 & 21.33 & 19.52 & 58.12 \\
& 4 & 1.76 & 3.23 & 41.41 & 20.66 & 32.94 \\
Kuwait & 6 & 1.83 & 3.41 & 42.01 & 20.70 & 32.05 \\
& 1 & 4.61 & 30.88 & 3.23 & 28.97 & 32.31 \\
& 4 & 4.52 & 37.87 & 23.56 & 15.38 & 18.67 \\
Oman & 6 & 4.10 & 36.81 & 28.22 & 13.95 & 16.93 \\
& 1 & 4.60 & 7.04 & 13.50 & 19.80 & 55.06 \\
& 4 & 5.82 & 16.37 & 18.71 & 14.96 & 44.13 \\
Qatar & 6 & 6.06 & 16.34 & 19.46 & 14.72 & 43.42 \\
& 1 & 0.79 & 14.72 & 8.87 & 28.24 & 47.38 \\
\multirow{4}{*}{ Saudi Arabia } & 4 & 5.18 & 18.64 & 10.48 & 26.52 & 39.18 \\
& 6 & 5.65 & 18.49 & 10.39 & 26.35 & 39.11 \\
& 1 & 5.02 & 2.01 & 26.24 & 2.67 & 64.06 \\
UAE & 4 & 8.70 & 11.22 & 25.29 & 7.32 & 47.48 \\
& 6 & 9.39 & 11.01 & 25.55 & 7.24 & 46.81 \\
& 1 & 1.53 & 11.04 & 47.42 & 1.38 & 38.63 \\
\hline \hline
\end{tabular}

\section{Conclusion}

Given the pegged exchange rates arrangement of the GCC countries against the US dollar for a long time, they fear that dollar depreciation against the major countries would bring imported inflation to their countries. The point in case is their experience with their inflations in the last decade when for five years dollar depreciated more than $40 \%$. Only few studies, as discussed and mentioned above, are available to understand the determinants of their inflation. These studies based on macro-level correlation studies (either time-series or panel data set) between exchange rates and consumer prices show very low level of pass-through from the exchange rate depreciation to the consumer price inflation. One of the plausible reasons of such low pass-through is that the prices of the imported goods could be broken into two components of foreign prices and the exchange rates and if these components move in the opposite direction there would be no pass-through to the domestic prices. Thus, instead of focusing on the correlation of exchange rates and prices, this study has identified the fundamental shocks (foreign and domestic) to the economy 
and tests their effects on consumer prices. This exercise seems more fruitful in understanding the determinants of the consumer prices of these countries.

This paper uses structural VAR model to generate impulse response that matches and complements the results of the macro-level studies mentioned above. The impulse response analysis shows that exchange rates, oil price, foreign trading partners' prices have generally positive effects on the consumer prices of these countries. An anomaly is also observed in relation to the supply shocks as the consumer prices of Bahrain, Qatar, Saudi Arabia, and the UAE rise (instead of expected fall) following the supply shock. Variance decompositions results show besides the own CPI shock, oil price, exchange rate, and foreign price shocks all contribute to the changes in the consumer prices of the different countries to a different extent.

\section{References}

Akram, Q.F. (2009). Commodity Prices, Interest Rates and the Dollar. Energy Economics, 31, 838-851. http://dx.doi.org/10.1016/j.eneco.2009.05.016

Alhajji, A. F. (2004). The Impact of Dollar Devaluation on the World Oil Industry: Do Exchange Rates Matter? OGEL 4. Retrieved from www.ogel.org/article.asp?key $=1561$

Bayoumi, T. A., \& B. Eichengreen. (1994), Monetary and Exchange Rate Arrangements for NAFTA, Journal of Development Economics, 43(1), 125-65. http://dx.doi.org/10.1016/0304-3878(94)90026-4

Blanchard, O. J., \& D. Quah. (1989). The Dynamic Effects of Aggregate Demand and Supply Disturbances. American Economic Review, 79(4), 655-73.

Clarida, R., \& J. Gali. (1994). Sources of Real Exchange Rate Fluctuations: How Important are Nominal Shocks?. Carnegie-Rochester Conference Series on Public Policy, 41, 1-56. http://dx.doi.org/10.1016/0167-2231(94)00012-3

Espinoza, R., \& A. Senhadji. (2011). How Strong are Fiscal Multipliers in the GCC? An Empirical Investigation. IMF Working Paper WP/11/61, Washington, D.C.

Frankel, J. A., D. C. Parsley, \& S-J. Wei. (2012). Slow Passthrough around the World: A New Import for Developing Countries? Open Economies Review, 23(2), 213-251. http://dx.doi.org/10.1007/s11079-011-9210-8

Hasan, M., \& A. Nakibullah. (2015). Price Level and Inflation in the GCC Countries. International Review of Economics and Finance, 39, 239-252. http://dx.doi.org/10.1016/j.iref.2015.04.008

Hasan, M., \& H. Alogeel. (2008). Understanding the Inflationary Process in the GCC Countries: The case of Saudi Arabia and Kuwait. IMF working paper 08/193. (Washington D.C.: IMF).

Kandil, M., \& H. Morsy. (2011). Determinants of Inflation in GCC, Middle East Development Journal, 3, 141-158. http://dx.doi.org/10.1142/S1793812011000351

Kim, W. J., \& S. Hammoudeh. (2013). Impacts of Global and Domestic Shocks on Inflation and Economic Growth for Actual and Potential GCC Member Countries. International Review of Economics and Finance, 27, 298-312. http://dx.doi.org/10.1016/j.iref.2012.10.009

Mishkin, F. (2008). Exchange Rate Pass-Through and Monetary Policy, At the Norges Bank Conference on Monetary Policy, March, Oslo, Norway.

Nakibullah, A. (2016). Exchange Rate Pass-Through in the GCC Countries: A Dynamic Panel Data Approach. Empirical Economics Letters, Forthcoming.

Shambaugh, J. (2008). A New Look at Pass-Through. International Journal of Money and Finance, 27, 560-591. http://dx.doi.org/10.1016/j.jimonfin.2008.01.009

Sturm, M., J. Strasky, P. Adolf, \& D. Peschel. (2008). The Gulf Cooperation Council Countries Economic Structures, Recent Developments and Role in the Global Economy, Occasional Paper Series No. 92, July, European Central Bank.

World Bank. (2015). Global Economic Prospects, Chapter 4, January, 155-167.

Zhang, Y. (2013). The Links between the Price of Oil and the Value of US Dollar. International Journal of Energy Economics and Policy, 3(4), 341-51.

Zhang, Y., Y. Fan, H. Tsai, \& Y. Wei. (2008). Spillover Effects of US Dollar Exchange Rate on Oil Prices. Journal of Policy Modeling, 30, 973-991. http://dx.doi.org/10.1016/j.jpolmod.2008.02.002 